\title{
The impact of R\&D subsidies during the crisis
}

\author{
Martin Hud $^{\mathrm{a}, \mathrm{b}, *}$, Katrin Hussinger ${ }^{\mathrm{a}, \mathrm{c}, \mathrm{d}}$ \\ a ZEW Centre for European Economic Research, Mannheim, Germany \\ ${ }^{\mathrm{b}}$ Maastricht University, The Netherlands \\ c University of Luxembourg, Luxembourg \\ ${ }^{\mathrm{d}}$ K.U Leuven, Department of Managerial Economics, Strategy and Innovation, Belgium
}

\section{A R T I C L E I N}

\section{Article history:}

Received 13 April 2014

Received in revised form 8 June 2015

Accepted 8 June 2015

\begin{tabular}{l}
\hline JEL: \\
C14 \\
C21 \\
G01 \\
H50 \\
O38 \\
Keywords: \\
R\&D \\
Subsidies \\
Policy evaluation \\
Economic crisis \\
Treatment effects
\end{tabular}

\begin{abstract}
A B S T R A C T
This study investigates the impact of public R\&D subsidies on R\&D investment of small and mediumsized enterprises (SMEs) in Germany during the most recent economic crisis. Our analysis is based on firm-level data of the Mannheim Innovation Panel (MIP) covering the period 2006-2010. While we find an overall positive effect of R\&D subsidies on SMEs' R\&D investment behavior, there is evidence for a crowding out effect for the crisis year 2009. In 2010, when the German economy started to recover, the subsidy effect is smaller than in the pre-crisis years, but positive and significant. Additional tests indicate that the temporary crowding out effect was caused by reluctant innovation investment behavior of the subsidy recipients rather than by Germany's countercyclical innovation policy during the crisis.
\end{abstract}

(c) 2015 Elsevier B.V. All rights reserved.

\section{Introduction}

The global economic crisis of 2008/2009 has severely affected the OECD economies. The unemployment rate has reached a postwar height of $8.5 \%$ in October 2009, the GDP declined by $4 \%$ in 2009 as compared to 2008 (OECD, 2012a), and long-term investments like innovation expenditures decreased significantly in a range of countries including Canada, Sweden and the UK (OECD, 2012b; Filipetti and Archibugi, 2011).

Private sector innovation and research and development (R\&D) activities substantially contribute to sustainable growth (Griliches, 1979; Grossman and Helpman, 1994; Aghion and Howitt, 2009; Doraszelski and Jaumandreu, 2013). Even a short-term decline or stagnation of these activities can have detrimental consequences in the long run. Policymakers are well aware of the importance of private sector R\&D and also of the fact that private R\&D spending is lower than socially desirable, even in boom periods. For that reason,

\footnotetext{
* Corresponding author at: Centre for European Economic Research (ZEW), Department of Industrial Economics and International Management, L 7, 1, D-68161 Mannheim, Germany. Fax: +49621 1235170.

E-mail address: hud@zew.de (M. Hud).
}

public support for R\&D activities is particularly important in times of an economic downturn.

R\&D investment is risky and the returns are uncertain and long-term. During recessions, not only firms facing financial constraints are likely to reduce their investment in $R \& D$ (Schumpeter, 1939; Freeman et al., 1982). R\&D investments might also be cut in response to a decreased demand in recession periods (Stiglitz, 1993; Aghion and Saint-Paul, 1998). Furthermore, it has been shown that the responsiveness of companies to policy initiatives is weaker in times of economic uncertainty (Bloom et al., 2007; Bloom, 2008). Uncertainty raises the real option value of investments, which makes firms more cautious concerning their R\&D investment decisions during recessions.

In order to prevent firms from reducing their R\&D expenses and to maintain the national R\&D capacities, policymakers in many industrialized countries, including Austria, Denmark and Sweden, reacted immediately to the most recent crisis and increased the public R\&D budgets (OECD, 2012b). In Germany, the private sector reduced R\&D expenses by $2.9 \%$ (Fig. 1), while the German Federal Ministry for Education and Research (BMBF) reacted to the crisis by increasing its budget by $9 \%$ in 2009 as compared to 2008. 


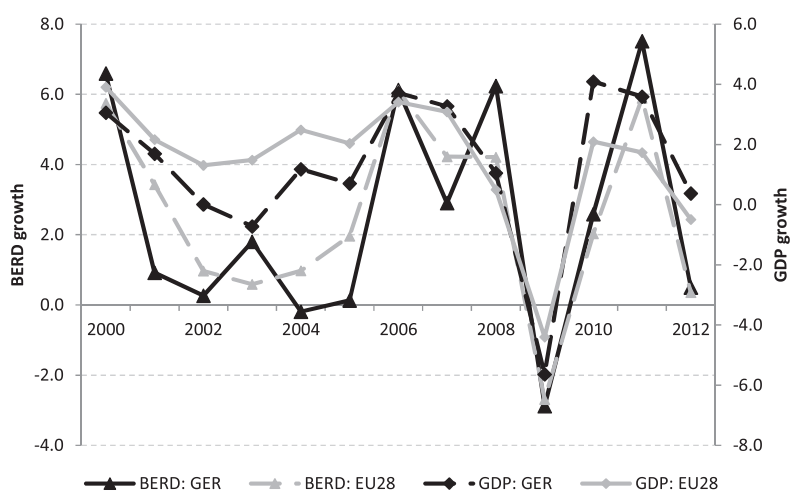

Fig. 1. Annual real GDP growth and real Business Enterprise Expenditure on R\&D (BERD) growth in Germany and EU28 between 2000 and 2012, in \%.

Source: OECD and OECD (2013). Own calculations. Real GDP and BERD growth rates are calculated based on GDP and BERD at constant 2005 USD.

This paper empirically examines the effects of the BMBF's public $R \& D$ subsidy program on firms' $R \& D$ investment during the most recent crisis. Our analysis is based on firm-level data of the Mannheim Innovation Panel (MIP) and on public R\&D subsidy data provided by the BMBF. We focus on small and medium-sized enterprises (SMEs) because these firms are expected to be more vulnerable during an economic downturn as compared to large enterprises. Our sample covers the period of 2006-2010, with 2009 marking the peak of the crisis period in Germany (and the EU) as revealed in Fig. $1 .^{1}$

Our empirical strategy consists of several steps. We rely upon propensity score matching in order to assess whether R\&D subsidies stimulate additional R\&D investment over the sample period. The matching estimator accounts for the fact that subsidies are not randomly distributed among SMEs, but that companies self-select themselves into the funding scheme. This procedure provides us with an estimate of the average effect of subsidies on the subsidized companies' R\&D investment. In the next step, we compare the effectiveness of the treatment of the crisis period to the precrisis (2006-2008) and post-crisis (2010) periods. In the final step, we test whether SMEs subsidized during the crisis are less promising innovators than SMEs subsidized before the crisis or whether the investment behavior of subsidy recipients changed during the crisis. The former could be a consequence of an expanded subsidy program during the crisis that could have lowered the average "quality" of the pool of subsidy recipients.

Our results show that R\&D subsidies lead to an additionality effect for the overall period. Only for the crisis year, we find evidence for a crowding out effect from which SMEs are already recovering again in the first post-crisis year. The crowding out effect of the crisis year can be indicative of reluctant R\&D investment behavior of the subsidy recipients or of the countercyclical innovation policy that may have changed the average "quality" of the pool of subsidy recipients during the crisis. Our further empirical tests suggest that the crowding out effect is caused by SMEs' reluctance to invest in R\&D during a crisis period. We do not find support for the hypothesis that the crowding out effect is related to a lower average "quality" of subsidized firms in the crisis and post-crisis years due the expanded subsidy program.

Although our main finding is that the average additionality effect is negative for the crisis year 2009, the countercyclical

\footnotetext{
1 Germany was already severely affected by the crisis in the last quarter of 2008 reaching the peak in 2009. This does not show up in the aggregate annual data though. We therefore refer to 2009 as the crisis year in the remainder of the paper.
}

innovation policy is likely to have had a stabilizing effect on the economy. It may have helped SMEs to keep their R\&D personnel and to maintain national innovation capacities. ${ }^{2}$

The remainder of the paper is organized as follows. The next section surveys related literature. Section 3 presents the empirical strategy. The data set is described in Section 4. The results are discussed in Section 5. The last section concludes.

\section{Literature review}

\subsection{The rationale for public $R \mathcal{E} D$ subsidies}

The economic rationale for R\&D subsidies to the private sector is that the level of privately financed R\&D in the economy is lower than socially desirable. This is because R\&D has the characteristics of a public good as it generates positive external effects, which cannot be internalized by the innovating companies (Arrow, 1962). In the absence of public subsidies, projects that would generate positive benefits for society but do not cover the private costs, would hence not be carried out. This type of market failure is the main reason for governments to subsidize private R\&D projects. Public funding reduces the price for private investors so that the otherwise too expensive innovation projects are carried out. The policymakers' objective is twofold regarding R\&D subsidies. On the one hand, the aim is to maintain national innovation capabilities, the national R\&D and employment level, especially in recession periods, where typically subsidies to the private sector are preferred over public procurement because of the potential of additionality effects. On the other hand, the government's interest is to generate more innovation outcome. Public subsidies can help the economy recovering from a crisis by fostering the creation of new innovations leading to economic growth.

The positive effect of R\&D subsidies on firms' R\&D activities, however, cannot be taken for granted. In practice, firms always have an incentive to apply for public R\&D support due to relatively low application costs, even if the expected net return of the project is positive and although the R\&D projects could be conducted with own financial means. Once the application was successful, firms can use the public grant to replace private with public investment. This is called a "crowding out" effect (e.g., David et al., 2000). If the majority of firms acted this way, public R\&D subsidies would lead the economy to a lower growth path in the long-term. The likelihood of crowding out may be particularly high during recession periods as firms face declining sales and financial markets that hamper the financing of R\&D. Firms may use the additional risk-free money to service short-term debt or to maintain their production capacities.

A vast empirical literature has investigated the question whether R\&D subsidy programs lead to a crowding out effect or stimulate R\&D activities in the private sector. The majority of the studies find that R\&D subsidies lead to an additionality effect (see Zúñiga-Vicente et al., 2014, for a recent survey). The early literature up to the year 2000 - as surveyed by David et al. (2000) and Klette et al. (2000) - is criticized for disregarding a potential selection bias of firms into R\&D subsidy programs. On the one hand, companies with larger R\&D capacity are more likely to apply for R\&D subsidies. On the other hand, these companies may be more likely to receive the public funds if the government wants to maximize the returns to the subsidy program. A simple comparison of subsidized and non-subsidized firms hence leads to biased results.

The more recent literature with focus on the firm level as surveyed by Cerulli and Poti (2010) and Zúñiga-Vicente et al. (2014)

\footnotetext{
2 According to the German R\&D statistics, R\&D personnel is the largest cost unit in a firm's R\&D process (Stifterverband, 2013).
} 
takes the selection problem into account. Prominent methods that have been used to account for sample selection are matching methods (e.g., Czarnitzki and Fier, 2002; Almus and Czarnitzki, 2003; Czarnitzki et al., 2007; for heterogeneous treatments), instrumental variables methods (e.g., Wallsten, 2000), and selection models (e.g., Busom, 2000; Hussinger, 2008). ${ }^{3}$ Most of the studies that account for selection issues report a positive effect of the subsidy on the subsidized firms' R\&D expenses as well. ${ }^{4}$

With focus on Germany, prior literature shows exclusively positive average effects of $R \& D$ subsidies. For the direct project subsidy program of the BMBF, which is also subject to our study, Czarnitzki and Fier (2002), Almus and Czarnitzki (2003), Czarnitzki and Hussinger (2004), Czarnitzki et al. (2007), Hussinger (2008), and Aerts and Schmidt (2008) report that the subsidy leads on average to additional $R \& D$ expenses.

\subsection{Private innovation expenditure during economic downturns}

The economic literature has developed different views on the impact of an economic downturn on innovation activities. One line of research advocates countercyclical behavior of R\&D investment. In times of an economic downturn, profitability declines encourage firms to seek for measures to improve productivity. At the same time, opportunity costs of reallocating productive assets from manufacturing to R\&D are relatively low because of a limited demand for goods and services (Stiglitz, 1993; Aghion and Saint-Paul, 1998) which is in line with the Schumpeterian notion of creative destruction.

The contrary perspective suggests that innovation behavior is procyclical. Innovation strongly depends on demand so that there is no incentive to introduce new products into the market if demand is low (Schmookler, 1966; Shleifer, 1986). Further, $R \& D$ is often financed by the firm's free cash flow that depends on the company's current profit so that financial constraints during an economic downturn reduce investment in R\&D (Hall, 1992; Himmelberg and Petersen, 1994; Harhoff, 1998; Rafferty and Funk, 2008).

\subsection{Private innovation expenditure during the most recent economic crisis}

The most recent crisis caused an overall decline of innovation activities across OECD countries, whereby different countries have been affected to a different degree (OECD, 2012b; Makkonen, 2013). Some OECD economies show significantly reduced R\&D figures for the private sector during the crisis, among them Canada, the Czech Republic and the Netherlands. Others show slightly decreased R\&D expenditures during the crisis such as Austria, Belgium, and Germany. In Germany, business enterprise expenditure on R\&D (BERD) decreased by $2.9 \%$ in 2009 compared to 2008. A possible reason is that the federal government adopted a countercyclical policy and increased its government spending (government budget appropriations or outlays for R\&D, GBAORD) by $9 \%$ between 2007 and 2009 (OECD, 2012a; Makkonen, 2013). Other economies including China, Estonia and Hungary show an upwards trend of private R\&D expenditure throughout the crisis (OECD, 2012b).

\footnotetext{
3 Gonzalez et al.(2005) and Takalo et al. (2008) present structural models to access the effect of subsidies on the subsidized firms.

4 Exceptions are Busom (2000), who finds a partial crowding out effect for Spain, and Wallsten (2000), who reports a substitutive effect of subsidies for the U.S. SBIR program. Gelabert et al. (2009) find differences in the effectiveness of public subsidies depending on the level of appropriation in the firm's industry.
}

Heterogeneous responses to the crisis have also been observed at the firm level. Overall, European firms' innovation activities declined during the crisis with a few exceptions comprising some new, fast growing firms and some highly innovative firms that sustained high innovation performance throughout the crisis (Archibugi et al., 2013a). In addition, a few small firms and new entrants show greater readiness to "swim against the stream" with regards to their innovation strategy after the crisis (Archibugi et al., 2013b). For Latin America, Paunov (2012) shows that many firms stopped ongoing R\&D projects during the crisis. With focus on public R\&D subsidies, Paunov (2012) finds that the likelihood to stop projects correlates negatively with the receipt of public funding and concludes that public funding schemes are an important means to foster countercyclical investment behavior. A potential selection bias of firms into subsidy programs is not taken into account.

Based on a survey, Kulicke et al. (2010) conclude that the majority of companies in Germany would have been forced to stop or postpone their R\&D project during the crisis as well. Rammer (2011) reports that the innovation expenditures of German firms in the research-intensive manufacturing sector decreased by $9.5 \%$ and by $16.7 \%$ in other manufacturing industries (see Rammer, 2011; Table 2). ${ }^{5}$ Especially small firms were affected. About 2000 SMEs stopped their innovation activities (Rammer, 2011).

A recent study investigates the macroeconomic effects of $R \& D$ subsidies granted by the "Central Innovation Program for SMEs" (ZIM) program that was launched in 2008 (Brautzsch et al., 2015). Brautzsch et al. (2015) conclude that the ZIM program stabilized production, value added and employment during the crisis which prevented a GDP decline of $0.5 \%$. Our study complements their findings by providing microeconomic evidence for the effects of R\&D subsidies on SMEs' R\&D investment during the crisis. In contrast to Brautzsch et al. (2015), our data also allows us to compare the crisis behavior of SMEs with the pre-crisis period.

\section{Empirical strategy}

Our empirical approach has three different parts. The first part evaluates the effectiveness of R\&D subsidies for the entire sample period. The second part compares the effect of subsidies in the crisis year to pre- and post-crisis years. In the last part of the analysis, we investigate possible reasons for a different effect of subsidies in crisis and non-crisis years.

\subsection{Effectiveness of RED subsidies}

The aim of our policy evaluation is to assess the average effect of the public subsidy on the R\&D spending of the subsidized SMEs. Since a simple comparison between treated (subsidized) and nontreated (non-subsidized) SMEs is likely to be biased due to selection problems, ${ }^{6}$ our empirical approach aims at investigating what firms in the treated condition would have spent on R\&D if they had not received the subsidy, i.e., the counterfactual situation. This average treatment effect on the treated (ATT) is defined as follows:

$\mathrm{ATT}=E\left(Y_{1}-Y_{0} \mid S=1\right)=E\left(Y_{1} \mid S=1\right)-E\left(Y_{0} \mid S=1\right)$

where $Y_{1}$ is the R\&D spending of the SMEs having received the treatment (=subsidy) and $Y_{0}$ is the R\&D spending of SMEs that did not receive a subsidy and $S$ depicts the actual treatment status. This

\footnotetext{
5 Rammer's (2011) calculations are based on the same survey that we use for the empirical analysis.

${ }^{6}$ For a detailed discussion of the selection problem see e.g., Blundell and Costas Dias (2000).
} 
equation indicates a missing data problem: while we can observe $\left(Y_{1} \mid S=1\right)$, i.e., the R\&D spending of a subsidized firm, we cannot observe what the subsidized firm would have spent on R\&D without the subsidy $\left(Y_{0} \mid S=1\right)$

Constructing a valid proxy for the counterfactual situation is the main issue in empirical policy program evaluation. Econometric techniques serving to overcome this problem comprise difference-in-difference (DID) estimations, control function approaches (selection models), instrumental variable (IV) estimations, and matching techniques. Due to highly unbalanced panel data and a lack of reliable instruments and exclusion restrictions, we choose a matching approach. The intuition behind the matching approach is to proxy the counterfactual situation, i.e., the investment of a treated company in the absence of the treatment, by the investment of the most similar non-treated observation. Functional form assumptions and distributional assumptions about the error terms are not required. The disadvantage of the matching approach is that it only accounts for selection based on observable firm characteristics. Prior studies focusing on the effectiveness of our subsidy program in Germany, however, show comparable results independent of the method that was employed (see e.g., Almus and Czarnitzki, 2003; Czarnitzki et al., 2007; Hussinger, 2008).

We apply a nearest neighbor propensity score matching. This means that we match each subsidy recipient with the single most similar SME in the control group of the non-subsidized SMEs. The pairs are chosen based on the similarity in the estimated probability of receiving a subsidy, i.e., the propensity score. Matching on the propensity score avoids a "curse of dimensionality" because all information is bundled in the propensity score which is then used as the single matching argument (Rosenbaum and Rubin, 1983). In addition, we require that the selected control observation is observed in the same year as the treated observation. This is crucial for our analysis because we are interested in comparing treatment effects across years. We further demand that the control observations are located within the same geographical area in Germany by distinguishing between East and West German companies. We apply this distinction because the funding likelihood as well as the infrastructure for innovation differs between the two regions.

The matching estimator's main disadvantage is its reliance on the conditional independence assumption (CIA). This means that the assignment to treatment is required to be independent of the outcomes, in our case the R\&D investment, conditional on a set of observable characteristics (Rubin, 1977). The CIA is satisfied if all information affecting the treatment assignment and the outcome is included in the set of observable characteristics. If so, the observed non-treated outcome $E\left(Y_{0} \mid S=0\right)$ is a valid proxy for the unobservable counterfactual outcome $E\left(Y_{0} \mid S=1\right)$. Unfortunately, it is not possible to formally test the CIA. However, we are confident that our rich set of control variables suffices. ${ }^{7}$ A further requirement of the matching method is that there has to be sufficient overlap between the treated and the control group in terms of their propensity to receive a public subsidy (common support). In order to guarantee common support, we calculate the minimum and the maximum of the propensity scores of the potential control group, and delete observations on treated firms with probabilities larger than the maximum and smaller than the minimum in the potential control group. If the CIA and the common support are fulfilled, the

\footnotetext{
7 A similar set of control variables has been used in a variety of studies that evaluate the effects of R\&D subsidies based on similar data sets employing a matching approach (e.g., Czarnitzki and Fier, 2002; Almus and Czarnitzki, 2003; Czarnitzki et al., 2007; Czarnitzki and Lopes Bento, 2013).
}

ATT will be identified and consistently estimated by the following equation $^{8,9}$ :

$\mathrm{ATT}=\left(Y_{1} \mid X=x, S=1\right)-E\left(Y_{0} \mid X=x, S=0\right)$

\subsection{Effectiveness of RED subsidies in crisis and non-crisis years}

After the identification of the ATT, we investigate whether the effect of subsidies differs in the crisis and non-crisis years by running an OLS regression of the ATT on a set of time dummies $d$.

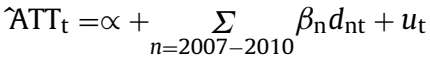

There are two different possible scenarios. On the one hand, one can expect that the subsidies are more effective in the crisis year because firms may face more severe financial constraints so that the subsidy increases R\&D investment substantially as compared to the counterfactual situation. On the other hand, a lower treatment effect can occur in the crisis year if firms match the public funds with less private investments than they would have made in noncrisis years or replace private investments by public funds.

\subsubsection{Explanations for possible different effects of $R \mathcal{E} D$ subsidies in crisis and non-crisis years}

In the final part of the analysis, we investigate possible explanations for the potential differences of the effectiveness of R\&D subsidies in crisis and non-crisis years. Such differences can be motivated by (a) an altered funding policy in crisis times or (b) a change of behavior of grant recipients in crisis times:

(a) During the past crisis, direct project funding has been increased in terms of granted amounts per project and number of projects funded. This can reduce the ATT because if more projects are funded the average "quality" of the recipients is likely to be lower than in non-crisis years.

(b) Subsidy recipients may face tighter budget constraints during the crisis. In response, they might invest less into the subsidized $\mathrm{R} \& \mathrm{D}$ projects than they would have invested in non-crisis years.

In order to analyze whether the change in innovation policy affected the effect of R\&D subsidies during the crisis, we compare first-time subsidized firms in crisis and non-crisis years. If a lower subsidy effect would be caused by a lower "quality" of funded firms during the crisis years, we should find a significant difference between these groups of firms in terms of success predictors like firm size or patent stock.

In order to investigate whether companies changed their R\&D investment behavior, we repeat the analysis described in the Section 3.2 for the subsample of SMEs that received subsidies before, during and after the crisis. If we would find that these companies reduce their R\&D investment we could conclude that a potential decreased effectiveness of R\&D subsidies is caused by firms' reluctance to invest in $R \& D$ during the crisis rather than by the countercyclical innovation policy.

\footnotetext{
8 The details of our matching procedure (matching protocol) are provided upon request. Very similar matching protocols can be found e.g., in Czarnitzki and Hussinger (2004), Aerts and Schmidt (2008) and Czarnitzki and Lopes Bento (2013). ${ }^{9}$ A similar matching approach has been used among others by Czarnitzki and Fier (2002), Almus and Czarnitzki (2003), Czarnitzki and Hussinger (2004), Goerg and Strobl (2007), Gonzalez and Pazo (2008), Czarnitzki and Lopes Bento (2013) and Hottenrott et al. (2014).
} 


\section{Data, variables and descriptive statistics}

\subsection{Data}

For our empirical analysis of a potential additionality effect of R\&D subsidies, we construct a database which consists of firmlevel information and their subsidy records. The firm-level data is provided by the Mannheim Innovation Panel (MIP), which is an annual survey conducted by the Centre for European Economic Research (ZEW) on behalf of the German Federal Ministry for Education Research (BMBF) since 1993. The MIP is the German contribution to the European Commission's Community Innovation Survey (CIS) and is based on the methodology proposed in the Oslo Manual for collecting innovation data (OECD and Eurostat, 2005). ${ }^{10}$

Information on the Federal Government's project funding is taken from BMBF's PROFI database, which is available to us from 1992 onwards. It contains information on all non-military R\&D projects funded by the BMBF. The BMBF program is the largest source of public R\&D funds for the business sector in Germany and accounts for more than $80 \%$ of the total public R\&D funding available to the business sector. The direct project funding program is open to all firms located in Germany. The official application form requires detailed information on the company and its planned $R \& D$ projects. There is a peer review process according to which grants are assigned as "matching grants" to the selected projects, which means that applicants themselves have to contribute at least $50 \%$ to the subsidized projects. The government sponsors at most $50 \%$ as is prescribed in the funding guidelines of the European Commission (1996) and in German regulations (BMBF and BMWi, 2001).

Further data sources comprise the European Patent Office (EPO) providing us with firms' patent applications since 1979, the credit rating agency Creditreform and the Federal Statistical Office of Germany. That latter office provides us with a measure for the business cycle. We constructed the annual change of industry-level sales based on the 4-digit industry level data (NACE 2.0). ${ }^{11}$ The database of Creditreform provides us with firm age information and a credit rating indicator that proxies the firms' financial fitness.

The final sample covers the years 2006-2010 in order to cover the pre-crisis period (2006-2008), the crisis year (2009) and the first post-crisis year (2010). The choice of the time frame for our study is motivated by the fact that we want to exclude the recession $2002 / 2003$ and the following recovering period. Contrary to the most recent economic crisis, the recession 2002/2003 was expected by German companies (Rammer et al., 2003) so that we would not be able to identify causal effects. With regards to the recent economic crisis, Rammer (2011) shows that in the years 2006-2008 the actual innovation expenditures of German firms of all size classes were almost equal to the innovation expenditures planned in the previous year. Only in the crisis year 2009, a gap between planned and actual innovation expenses arises (see Fig. 1 in Rammer, 2011).

We restrict our sample to firms with less than 250 employees since SMEs are most sensitive to the business cycle (OECD, 2009). Our sample includes manufacturing as well as business related service sectors.

The final sample consists of 10,527 firm-year observations out of which 1016 received an R\&D subsidy from the BMBF.

\footnotetext{
10 For further details see Aschhoff et al. (2013) and Peters and Rammer (2013).

11 For a few cases we had to use the 3-digit level
}

Table 1

Overview of subsidized and non-subsidized firms over time.

\begin{tabular}{lrrrrrc}
\hline & 2006 & 2007 & 2008 & 2009 & 2010 & Total \\
\hline Not subsidized & 1,579 & 1,715 & 2,358 & 1,925 & 1,934 & 9,511 \\
Subsidized & 191 & 176 & 153 & 194 & 302 & 1,016 \\
First-time subsidized after 2008 & 6 & 5 & 8 & 15 & 93 & 127 \\
\hline
\end{tabular}

Note: Due to the panel structure of our data set, observations of firms subsidized for the first time after 2008 can also appear in 2006-2008.

\subsection{Variables}

\subsubsection{Treatment variable}

We measure treatment with a binary indicator that takes on the value 1 if a firm had been subsidized by the BMBF in the respective year. The indicator takes on the value 0 if a firm had not received any R\&D subsidy at all in the respective year, neither from the EU nor from the Federal Government nor from other sources. Thus, our control group solely consists of non-subsidized firms, allowing us to rule out side-effects from other subsidy programs. Table 1 shows the distribution of subsidized companies and unsubsidized companies in our sample over time. It becomes evident that the number of subsidized firms has increased during and after the crisis. The number of newly funded companies is still small in the crisis year 2009, but increases significantly in 2010 .

\subsubsection{Outcome variables}

We test potential additionality effects for six outcome variables in order to show robustness of the results with regards to different definitions of the dependent variable. $R D$ depicts a firm's total R\&D expenditure, which is measured in million EUR. PRIVRD is defined as the private $R \& D$ investment, i.e., $R D$ minus the subsidy received. Since these variables are distributed askew, we employ RDINT ( $R D$ over sales) as well as PRIVRDINT (PRIVRD over sales) in addition. Furthermore, we define $R D E M P$ ( $R D$ over number of employees) and PRIVRDEMP (PRIVRD over number of employees) as alternative measures for the R\&D intensity.

\subsubsection{Control variables}

Our control variables encompass firm size as measured by the $\log$ of the number of full time employees, Lemp. We expect that R\&D expenditure correlates with firm size. Thus, larger firms are more likely to apply for subsidies and to receive a grant if the government wants to maximize the likelihood of a positive outcome of the funded project by choosing companies with a superior innovation capacity. The logarithmic specification is chosen because of the skew distribution of the firm size variable.

If a firm is part of an enterprise group, this membership can improve the access to innovation capacity and also to information on governmental programs. This may result in a higher likelihood to apply for a subsidy. Further, governmental evaluators could be prone to subsidize firms that belong to a network of firms, being aware of potential knowledge spillovers within the enterprise group due to the subsidized project. We control for firms belonging to a firm group with a binary variable, Group. Firm groups with a foreign headquarter, Foreign, could, in contrast, be less likely to receive funding if the government would want to induce economic effects for the own country. The binary variable East indicates whether a firm is located in Eastern Germany or in the Western part of the country. East German firms could be more likely to receive a subsidy as this region is still in a catch-up process with regards to Western Germany. The log of firm age, Lage, covers potential firm age effects. Firms competing in foreign markets are more innovative than others (Arnold and Hussinger, 2005). Therefore, we also expect export-oriented firms to apply more frequently for R\&D subsidies. Our binary dummy Export indicates whether a firm has export sales 
or not. Furthermore, we account for a firm's innovation potential by past innovation success in terms of the company's patent stock. To construct the patent stock, we use patent applications from 1979 onwards which have been filed at the EPO. The patent stock in $t$ is calculated as a depreciated sum of all these patent applications until $t-1$ plus the (non-depreciated) patent applications in $t$. The depreciation rate is set to 0.15 , as is common in the literature (see e.g., Hall, 1990; Griliches and Mairesse, 1984). Due to collinearity concerns with firm size, the patent stock is normalized by the number of employees, Patemp.

To account for potential financial restrictions, particularly during the crisis period, we include Creditreform's credit rating index, Credit. ${ }^{12}$ This is an index representing a firm's solvency. The index ranges from 100 to 600 . The larger the index value, the lower is the credit rating and the ability to attract debt capital. Firms that have more problems to attract external finance might be more likely to apply for subsidies.

We also control for the receipt of past subsidies. Firms that received subsidies in the past have a high chance that a new application will be evaluated positively (Hussinger, 2008; Aschhoff, 2010). We use a dummy for past subsidy receipt with a four year lag to account for the fact that the average subsidized R\&D project lasts for about 3 years.

Another characteristic to be considered is the business climate of the firm's industry sector. SMEs usually participate only in one or a few product markets. In case of economic downturns, these firms may not have the opportunity to compensate a serious decrease of demand in one of their few markets. We control for the companies' business environment by including an industry-specific sales growth rate, Salesgrowth.

To avoid potential endogeneity, we lag all time-variant explanatory variables and consider Group, Foreign, East as time-invariant and Salesgrowth and Lage as exogenous to the firm.

\subsection{Descriptive statistics}

Table 2 shows descriptive statistics, comparing the variables' mean values of non-subsidized and subsidized firms. Significant $t-$ tests indicate systematic differences between the mean values of the variables for subsidized and non-subsidized firms. For example, subsidized firms score higher on each R\&D input measure. They have more patents per employee and more employees in general, and are more likely to be exporters. Further, subsidized SMEs are younger and are more frequently located in Eastern Germany. Subsidized SMEs, on average, reveal a higher business index which describes that the industries of the subsidy recipients have experienced a larger upswing as compared to the previous period than the industries of non-subsidized companies. This suggests that SMEs are more likely to apply for and receive a subsidy if the industry is experiencing an upswing. Further, the credit rating between non-subsidized and subsidized firms does not differ significantly. A value of about 225 means a "good financial standing." 13

\footnotetext{
12 We also employ a missing value correction. The missing values of Credit are set to zero. An additional binary dummy, Credit_mvd, that takes on the value 1 if Credit equals zero, is included in the estimations.

13 Similar results for the exogenous variables appear when comparing them between the pre-crisis and the (post-) crisis periods. However, almost no significant differences are found for the outcome variables (see Table A1).
}

Table 2

Descriptive statistics for the whole sample, by subsidy status.

\begin{tabular}{|c|c|c|c|c|c|}
\hline & \multicolumn{2}{|c|}{$\begin{array}{l}\text { Unsubsidized } \\
\text { firms } N=9511\end{array}$} & \multicolumn{2}{|c|}{$\begin{array}{l}\text { Subsidized } \\
\text { firms } N=1016\end{array}$} & \multirow[t]{2}{*}{$t$-Test } \\
\hline & Mean & Std. dev. & Mean & Std. dev. & \\
\hline \multicolumn{6}{|l|}{ Covariates } \\
\hline Sub_t-4 & 0.006 & 0.079 & 0.338 & 0.473 & $* * *$ \\
\hline Patemp & 0.001 & 0.015 & 0.027 & 0.085 & $* * *$ \\
\hline Lemp & 3.165 & 1.093 & 3.460 & 1.091 & $* * *$ \\
\hline Foreign & 0.047 & 0.213 & 0.068 & 0.252 & $* *$ \\
\hline Export & 0.404 & 0.491 & 0.802 & 0.399 & $* * *$ \\
\hline Group & 0.213 & 0.409 & 0.247 & 0.432 & $* *$ \\
\hline Lage & 3.096 & 0.858 & 2.679 & 0.728 & $* * *$ \\
\hline East & 0.337 & 0.473 & 0.410 & 0.492 & $* * *$ \\
\hline Salesgrowth & 2.459 & 13.208 & 4.068 & 13.947 & $* * *$ \\
\hline Credit & 225.487 & 65.334 & 226.054 & 52.911 & \\
\hline Credit_mvd & 0.035 & 0.185 & 0.023 & 0.149 & $* *$ \\
\hline \multicolumn{6}{|c|}{ Controlling for period differences } \\
\hline Sub_t-4_period & 0.003 & 0.054 & 0.148 & 0.355 & $* * *$ \\
\hline Patemp_period & 0.000 & 0.005 & 0.014 & 0.066 & $* * *$ \\
\hline Lemp_period & 1.263 & 1.680 & 1.651 & 1.851 & $* * *$ \\
\hline Foreign_period & 0.017 & 0.127 & 0.029 & 0.167 & $* *$ \\
\hline Export_period & 0.156 & 0.363 & 0.390 & 0.488 & $* * *$ \\
\hline Group_period & 0.080 & 0.271 & 0.118 & 0.323 & $* * *$ \\
\hline Lage_period & 1.275 & 1.632 & 1.305 & 1.432 & \\
\hline East_period & 0.138 & 0.345 & 0.172 & 0.378 & $* * *$ \\
\hline Salesgrowth_period & -0.635 & 10.543 & 0.919 & 12.443 & $* * *$ \\
\hline Credit_period & 91.563 & 117.935 & 111.111 & 119.564 & $* * *$ \\
\hline Credit_mvd_period & 0.014 & 0.119 & 0.010 & 0.099 & \\
\hline \multicolumn{6}{|l|}{ Outcome variables } \\
\hline RD & 0.036 & 0.310 & 0.705 & 2.586 & $* * *$ \\
\hline PRIVRD & 0.036 & 0.310 & 0.577 & 2.310 & $* * *$ \\
\hline RDINT & 0.005 & 0.035 & 0.150 & 0.220 & $* * *$ \\
\hline PRIVRDINT & 0.005 & 0.035 & 0.098 & 0.184 & $* * *$ \\
\hline RDEMP & 0.001 & 0.004 & 0.013 & 0.023 & $* * *$ \\
\hline PRIVRDEMP & 0.001 & 0.004 & 0.009 & 0.020 & $* * *$ \\
\hline
\end{tabular}

Note: ${ }^{*} p<0.1 ;{ }^{* *} p<0.05 ;{ }^{* * *} p<0.01$. For reasons of clarity, we dropped the information on industry dummies and their period differences from this table.

\section{Empirical results}

\subsection{Funding propensity}

As described in Section 3, we employ a matching method to identify the causal effect of the subsidy treatment on R\&D investment. Thus, we have to find non-subsidized observations with the most similar characteristics to the subsidized observations. We determine the so-called nearest neighbors based on the propensity score, i.e., the likelihood of receiving a subsidy. In order to get an estimate for the propensity score, we estimate a probit model for the receipt of public subsidies. We allow that our control variables have a different impact on the receipt of subsidies in the pre-crisis period and thereafter by including interaction terms of all control variables with a year dummy for 2009 and 2010. Table 3 shows the results.

Apart from the dummy indicating membership of a firm group, the dummy indicating a foreign headquarter and the business situation, each variable reveals significant effects with the expected sign.

\subsection{Average treatment effect on the treated}

In a second step, we determine "twin observations" of nonsubsidized SMEs for each subsidized SME observation based on the propensity score and the additional two matching arguments - location in Eastern Germany and year of observation. Due to the common support criterion we have to drop two observations for which we cannot determine appropriate control observations. Table 4 shows the mean values for treated and control observations 
Table 3

Probit estimation of subsidy receipt.

\begin{tabular}{|c|c|c|}
\hline & Coefficients & Std. err. \\
\hline Sub_t-4 & $2.187^{* * *}$ & $(0.118)$ \\
\hline Patemp & $4.568^{* * *}$ & $(0.700)$ \\
\hline Lemp & $0.149^{* * *}$ & $(0.032)$ \\
\hline Foreign & 0.050 & $(0.127)$ \\
\hline Export & $0.775^{* * *}$ & $(0.075)$ \\
\hline Group & $-0.243^{* * *}$ & $(0.084)$ \\
\hline Lage & $-0.273^{* * *}$ & $(0.042)$ \\
\hline East & $0.245^{* * *}$ & $(0.065)$ \\
\hline Salesgrowth & -0.003 & $(0.004)$ \\
\hline Credit & $-0.002^{* *}$ & $(0.001)$ \\
\hline Credit_mvd & $-0.686^{* * *}$ & $(0.243)$ \\
\hline \multicolumn{3}{|l|}{ Industries } \\
\hline Mining & $-1.130^{* * *}$ & $(0.294)$ \\
\hline Low-tech manufacturing & $-0.984^{* * *}$ & $(0.098)$ \\
\hline High-tech manufacturing & $-0.423^{* * *}$ & $(0.099)$ \\
\hline Energy, water, recycling & $-1.012^{* * *}$ & $(0.163)$ \\
\hline Wholesale & $-1.909^{* * *}$ & $(0.356)$ \\
\hline Transportation & $-1.389^{* * *}$ & $(0.202)$ \\
\hline ICT & -0.171 & $(0.117)$ \\
\hline Consulting, advertising & $-0.800^{* * *}$ & $(0.180)$ \\
\hline \multicolumn{3}{|l|}{ Years } \\
\hline 2007 & -0.069 & $(0.074)$ \\
\hline 2008 & $-0.293^{* * *}$ & $(0.074)$ \\
\hline 2009 & 0.117 & $(0.398)$ \\
\hline 2010 & 0.328 & $(0.398)$ \\
\hline Constant & $-0.645^{* *}$ & $(0.260)$ \\
\hline Observations & 10,527 & \\
\hline Log-likelihood & -1968 & \\
\hline McFadden R2 & 0.411 & \\
\hline Time dummies - chi2(4) & $24.26^{* * *}$ & \\
\hline Industry dummies - chi2(8) & $183.6^{* * *}$ & \\
\hline Period interactions - chi2(19) & $77.26^{* * *}$ & \\
\hline
\end{tabular}

Note: ${ }^{*} p<0.1 ;{ }^{* *} p<0.05 ;{ }^{* * *} p<0.01$; see Table A3 for additionally estimated coefficients.

after the matching. There no longer exist significant differences between the treated and the non-treated observations with regards to the control variables indicating that our matching specification is valid. Significant differences in the mean values of the outcome variables persist and can be given a causal interpretation now after the matching.

The subsidized firms show a higher R\&D activity independent of the definition of the outcome variable. Thus, we find an overall positive ATT signaling that firms increased their R\&D spending due to the subsidy. We can reject a crowding out. The ATT equals 0.370 (0.242) million EUR in terms of R\&D (private R\&D) expenditures. The ATT in terms of R\&D (private R\&D) over sales corresponds to $11.7 \%$ (6.6\%) points. For R\&D intensity as defined by R\&D over employment the ATT amounts to $0.8 \%(0.5 \%)$ points for $R \& D$ (private R\&D).
Table 4

Matching results.

\begin{tabular}{|c|c|c|c|c|}
\hline & $\begin{array}{l}\text { Unsubsidized } \\
N=998 \\
\text { Mean }\end{array}$ & $\begin{array}{l}\text { Subsidized } \\
N=998 \\
\text { Mean }\end{array}$ & $t$-Test & $p$-Values \\
\hline \multicolumn{5}{|l|}{ Covariates } \\
\hline Sub_t-4 & 0.347 & 0.333 & & 0.720 \\
\hline Patemp & 0.013 & 0.019 & & 0.115 \\
\hline Lemp & 3.539 & 3.461 & & 0.416 \\
\hline Foreign & 0.081 & 0.067 & & 0.528 \\
\hline Export & 0.804 & 0.802 & & 0.951 \\
\hline Group & 0.302 & 0.245 & & 0.134 \\
\hline Lage & 2.699 & 2.681 & & 0.739 \\
\hline East & 0.414 & 0.414 & & 1.000 \\
\hline Salesgrowth & 4.117 & 4.089 & & 0.982 \\
\hline Credit & 228.667 & 226.270 & & 0.649 \\
\hline Credit_mvd & 0.027 & 0.022 & & 0.704 \\
\hline \multicolumn{5}{|c|}{ Controlling for period differences } \\
\hline Sub_t-4_period & 0.152 & 0.141 & & 0.708 \\
\hline Patemp_period & 0.006 & 0.008 & & 0.293 \\
\hline Lemp_period & 1.755 & 1.626 & & 0.428 \\
\hline Foreign_period & 0.041 & 0.027 & & 0.379 \\
\hline Export_period & 0.390 & 0.384 & & 0.881 \\
\hline Group_period & 0.139 & 0.114 & & 0.374 \\
\hline Lage_period & 1.291 & 1.286 & & 0.963 \\
\hline East_period & 0.171 & 0.171 & & 1.000 \\
\hline Salesgrowth_period & 0.973 & 0.899 & & 0.949 \\
\hline Credit_period & 105.868 & 109.789 & & 0.684 \\
\hline Credit_mvd_period & 0.014 & 0.009 & & 0.595 \\
\hline \multicolumn{5}{|l|}{ Outcome variables } \\
\hline $\mathrm{RD}$ & 0.306 & 0.676 & $* * *$ & 0.001 \\
\hline PRIVRD & 0.306 & 0.548 & $* *$ & 0.021 \\
\hline RDINT & 0.029 & 0.146 & $* * *$ & 0.000 \\
\hline PRIVRDINT & 0.029 & 0.095 & $* * *$ & 0.000 \\
\hline RDEMP & 0.004 & 0.012 & $* * *$ & 0.000 \\
\hline PRIVRDEMP & 0.004 & 0.009 & $* * *$ & 0.000 \\
\hline
\end{tabular}

Note: ${ }^{*} p<0.1 ;{ }^{* *} p<0.05 ;{ }^{* * *} p<0.01$. For reasons of clarity, we dropped the industry dummies and their period differences from this table. Each difference of the mean values is not significantly different from zero.

\subsection{Average treatment effects in the course of time}

In this sub-section, we investigate potential changes of the average treatment effect on the treated over time. Table 5 presents the results of OLS regressions of the ATT on a set of year dummies. This specification's constant represents the ATT of the year 2006, our benchmark year. Table 5 shows that the ATTs on average are positive and significant as expected. Regarding R\&D expenses and private R\&D expenses, the ATT in 2009 is significantly lower and even negative $(0.763-1.006<0 ; 0.599-0.942<0)$ indicating a crowding out effect. In 2010, the effect is still lower but larger than zero $(0.763-0.522>0 ; 0.599-0.464>0)$, indicating a smaller, yet positive additionality effect. With regards to the R\&D intensity

Table 5

OLS results of the average treatment effects on time dummies.

\begin{tabular}{|c|c|c|c|c|c|c|}
\hline & $\mathrm{RD}$ & PRIVRD & RDINT & PRIVRDINT & RDEMP & PRIVRDEMP \\
\hline 2007 & $\begin{array}{l}-0.341 \\
(0.315)\end{array}$ & $\begin{array}{l}-0.329 \\
(0.268)\end{array}$ & $\begin{array}{l}0.010 \\
(0.025)\end{array}$ & $\begin{array}{r}-0.000 \\
(0.022)\end{array}$ & $\begin{array}{l}-0.000 \\
(0.003)\end{array}$ & $\begin{array}{r}-0.000 \\
(0.002)\end{array}$ \\
\hline 2008 & $\begin{array}{l}0.053 \\
(0.440)\end{array}$ & $\begin{array}{l}0.088 \\
(0.397)\end{array}$ & $\begin{array}{l}-0.005 \\
(0.027)\end{array}$ & $\begin{array}{c}-0.004 \\
(0.025)\end{array}$ & $\begin{array}{l}0.002 \\
(0.003)\end{array}$ & $\begin{array}{l}0.002 \\
(0.003)\end{array}$ \\
\hline 2009 & $\begin{array}{l}-1.006^{* * *} \\
(0.330)\end{array}$ & $\begin{array}{l}-0.942^{* * *} \\
(0.295)\end{array}$ & $\begin{array}{l}-0.056^{* *} \\
(0.023)\end{array}$ & $\begin{array}{l}-0.055^{* * *} \\
(0.020)\end{array}$ & $\begin{array}{l}-0.006^{* *} \\
(0.003)\end{array}$ & $\begin{array}{l}-0.006^{* *} \\
(0.002)\end{array}$ \\
\hline 2010 & $\begin{array}{l}-0.522^{*} \\
(0.295)\end{array}$ & $\begin{array}{l}-0.464^{*} \\
(0.254)\end{array}$ & $\begin{array}{l}-0.030 \\
(0.023)\end{array}$ & $\begin{array}{l}-0.033 \\
(0.020)\end{array}$ & $\begin{array}{l}-0.003 \\
(0.002)\end{array}$ & $\begin{array}{l}-0.003 \\
(0.002)\end{array}$ \\
\hline Constant & $\begin{array}{l}0.763^{* * *} \\
(0.285)\end{array}$ & $\begin{array}{l}0.599^{* *} \\
(0.245)\end{array}$ & $\begin{array}{l}0.135^{* * *} \\
(0.019)\end{array}$ & $\begin{array}{l}0.087^{* * *} \\
(0.017)\end{array}$ & $\begin{array}{l}0.010^{* * *} \\
(0.002)\end{array}$ & $\begin{array}{l}0.007^{* * *} \\
(0.002)\end{array}$ \\
\hline Observations & 998 & 998 & 998 & 998 & 998 & 998 \\
\hline R2 & 0.018 & 0.019 & 0.010 & 0.012 & 0.013 & 0.014 \\
\hline
\end{tabular}

Note: ${ }^{*} p<0.1 ;{ }^{* *} p<0.05 ;{ }^{* * *} p<0.01$; robust standard errors in parentheses. 


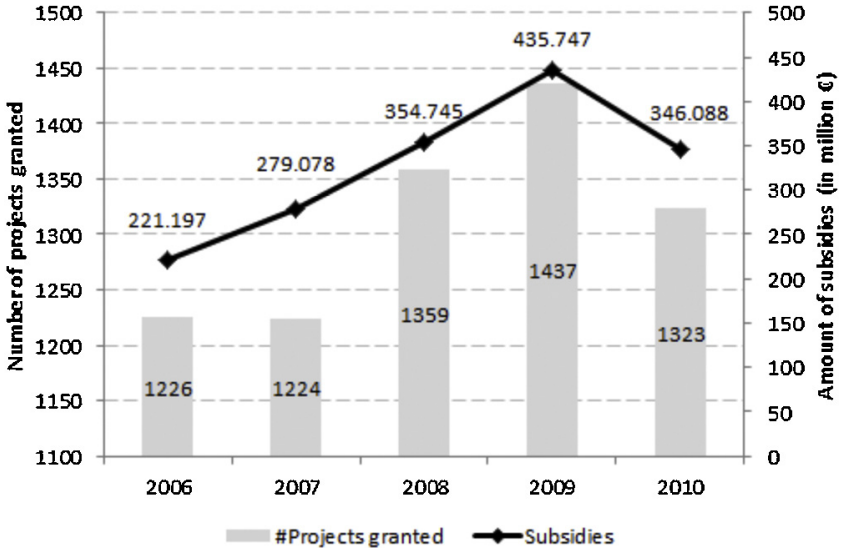

Fig. 2. Funding development for SMEs between 2006 and 2010. Source: BMBF's PROFI database. Own calculations.

variables we find a smaller additionality effect in the crisis year 2009 and no significant change for the post-crisis year.

Table A2 in the Appendix A shows a robustness check. We present results from pooled OLS regressions including interaction terms for the subsidy dummy and the year dummies. OLS models do not account for selection of SMEs into the subsidy program. The results are nevertheless in line with the finding above suggesting that the subsidies were less effective in the crisis year and post crisis years.

\subsection{Potential explanations for the lower ATT}

As mentioned in Section 3, the significantly lower ATT could be due to a changed funding policy during the crisis or due to an altered investment behavior of the firms. Fig. 2 depicts the allocation policy of the BMBF for SMEs over the observed period. In 2006,1226 projects were granted with an overall amount of about 221 million EUR. During the crisis, this amount corresponded to 435 million EUR for 1437 granted projects. This shows that the BMBF increased the number of projects granted as well as the total amount in 2009. In 2010, pre-crisis levels are achieved. The peak of 2009 could imply that the BMBF subsidized SMEs of lower average "quality" than in the pre-crisis years extending the pool of funded companies.

In order to provide a formal test for potential quality differences of subsidy recipients before and during the crisis, Table 6 presents a probit regression of our control variables on a binary variable that takes on the value 1 if the firm has been subsidized by the BMBF for the first time before the crisis of 2009 .
Table 6

Probit estimation of first-time funded firms.

\begin{tabular}{|c|c|c|}
\hline & Coefficients & Std. err. \\
\hline Patemp & 0.473 & $(0.813)$ \\
\hline Lemp & -0.053 & $(0.066)$ \\
\hline Foreign & -0.260 & $(0.246)$ \\
\hline Export & 0.177 & $(0.160)$ \\
\hline Group & 0.233 & $(0.157)$ \\
\hline Lage & -0.026 & $(0.082)$ \\
\hline East & 0.133 & $(0.120)$ \\
\hline Salesgrowth & -0.002 & $(0.005)$ \\
\hline Credit & 0.001 & $(0.002)$ \\
\hline Credit_mvd & -0.343 & $(0.496)$ \\
\hline \multicolumn{3}{|l|}{-} \\
\hline \multicolumn{3}{|l|}{ Industries } \\
\hline Low-tech manufacturing & $-0.421^{* *}$ & $(0.214)$ \\
\hline High-tech manufacturing & $-0.467^{* *}$ & $(0.193)$ \\
\hline Energy, water, recycling & $-1.162^{* * *}$ & $(0.301)$ \\
\hline Wholesale & $-1.217^{*}$ & $(0.652)$ \\
\hline Transportation & -0.185 & $(0.433)$ \\
\hline ICT & -0.352 & $(0.232)$ \\
\hline Consulting, advertising & -0.450 & $(0.297)$ \\
\hline \multicolumn{3}{|l|}{ Years } \\
\hline 2007 & 0.083 & $(0.274)$ \\
\hline 2008 & -0.168 & $(0.253)$ \\
\hline 2009 & $-0.519^{* *}$ & $(0.249)$ \\
\hline 2010 & $-1.379 * * *$ & $(0.201)$ \\
\hline Constant & $2.213^{* * *}$ & $(0.572)$ \\
\hline Observations & 1,175 & \\
\hline Log-likelihood & -320.3 & \\
\hline McFadden R2 & 0.204 & \\
\hline Industry dummies - chi2(7) & $17.89^{* *}$ & \\
\hline Time dummies - chi2(4) & $99.04^{* * *}$ & \\
\hline
\end{tabular}

Note: ${ }^{*} p<0.1 ;{ }^{* *} p<0.05 ;{ }^{* * *} p<0.01$.

It takes on the value 0 if the firm has been subsidized by the BMBF for the first time after the crisis started (i.e., after 2008). The sample only includes firms that have received subsidies at some point in their lifetime (1992-2010). If a first-time subsidy recipient before and during the (post-) crisis periods differed in terms of success indicators, we would see significant differences in these firm characteristics. The regression results, however, do not uncover systematic differences between first-time subsidy recipients in both periods indicating that the "quality" of the subsidy recipients did not differ. The only significant differences are found for some industry and time dummies. Therefore, we reject that the crowding out effect during the crisis year 2009 and the lower additionally effect in 2010 are caused by system-

Table 7

OLS results of the average treatment effects on time dummies - subsample of companies that received R\&D subsidies before, during and after the crisis.

\begin{tabular}{|c|c|c|c|c|c|c|}
\hline & $\mathrm{RD}$ & PRIVRD & RDINT & PRIVRDINT & RDEMP & PRIVRDEMP \\
\hline 2007 & $\begin{array}{l}-0.341 \\
(0.315)\end{array}$ & $\begin{array}{l}-0.329 \\
(0.268)\end{array}$ & $\begin{array}{l}0.010 \\
(0.025)\end{array}$ & $\begin{array}{l}-0.000 \\
(0.022)\end{array}$ & $\begin{array}{l}-0.000 \\
(0.003)\end{array}$ & $\begin{array}{l}-0.000 \\
(0.002)\end{array}$ \\
\hline 2008 & $\begin{array}{l}0.053 \\
(0.441)\end{array}$ & $\begin{array}{l}0.088 \\
(0.397)\end{array}$ & $\begin{array}{l}-0.005 \\
(0.027)\end{array}$ & $\begin{array}{c}-0.004 \\
(0.025)\end{array}$ & $\begin{array}{l}0.002 \\
(0.003)\end{array}$ & $\begin{array}{l}0.002 \\
(0.003)\end{array}$ \\
\hline 2009 & $\begin{array}{l}-1.070^{* * *} \\
(0.334)\end{array}$ & $\begin{array}{l}-1.008^{* * *} \\
(0.299)\end{array}$ & $\begin{array}{l}-0.056^{* *} \\
(0.024)\end{array}$ & $\begin{array}{l}-0.057^{* * * *} \\
(0.021)\end{array}$ & $\begin{array}{l}-0.006^{* *} \\
(0.003)\end{array}$ & $\begin{array}{l}-0.006^{* * *} \\
(0.002)\end{array}$ \\
\hline 2010 & $\begin{array}{l}-0.502^{*} \\
(0.303)\end{array}$ & $\begin{array}{l}-0.467^{*} \\
(0.262)\end{array}$ & $\begin{array}{l}-0.028 \\
(0.025)\end{array}$ & $\begin{array}{l}-0.033 \\
(0.022)\end{array}$ & $\begin{array}{c}-0.003 \\
(0.002)\end{array}$ & $\begin{array}{l}-0.003 \\
(0.002)\end{array}$ \\
\hline Constant & $\begin{array}{l}0.763^{* * *} \\
(0.286)\end{array}$ & $\begin{array}{l}0.599 * * \\
(0.245)\end{array}$ & $\begin{array}{l}0.135^{* * *} \\
(0.019)\end{array}$ & $\begin{array}{l}0.087^{* * *} \\
(0.017)\end{array}$ & $\begin{array}{l}0.010^{* * *} \\
(0.002)\end{array}$ & $\begin{array}{l}0.007^{* * *} \\
(0.002)\end{array}$ \\
\hline Observations & 896 & 896 & 896 & 896 & 896 & 896 \\
\hline $\mathrm{R} 2$ & 0.019 & 0.021 & 0.010 & 0.012 & 0.013 & 0.015 \\
\hline
\end{tabular}

Note: ${ }^{*} p<0.1 ;{ }^{* *} p<0.05 ;{ }^{* * *} p<0.01 ;$ robust standard errors in parentheses. 
atic differences between subsidy recipients before the crisis and afterwards. $^{14}$

The alternative explanation for the crowding out effect is that it is induced by firms' altered investment behavior. Firms had to cope with the negative consequences of the economic crisis. They may have allocated the funds that they would have spent on R\&D projects to business areas that they deemed more important during the crisis. According to Rammer (2011), firms that were most severely affected by the crisis have been R\&D active firms. We test whether firms' changed their R\&D investment behavior during the crisis by focusing on the subsample of SMEs that received subsidies before and during the crisis. We repeat the regressions presented in Table 5.

Table 7 shows the results. It appears that we find a crowding out effect for the crisis year 2009 and a smaller, but again positive treatment effect for the post crisis year 2010 for R\&D investment. This is in line with the presumption that SMEs changed their investment behavior during the crisis rather than the altered innovation policy causing the reduced treatment effect in 2009.

\section{Conclusion}

Our study examines the effects of R\&D subsidies on SMEs' R\&D spending during the most recent economic crisis. We start by investigating the average treatment effect on the treated (ATT) of direct R\&D subsidies in Germany during the period 2006-2010. Using propensity score nearest neighbor matching, we find an overall positive ATT for the observed period. Further results show that the ATT was negative in the crisis year 2009 indicating a crowding out effect. In the first post-crisis year, however, we find again evidence for a positive, but still small effect of R\&D subsidies on the subsidized SMEs' R\&D investment behavior signaling that German SMEs recovered fast after the crisis' peak.

In search for an explanation for the crowding out effect in 2009, we investigate two potential causes. We analyze whether the countercyclical innovation policy during the crisis is responsible for the crowding out effect or whether a different investment behavior of subsidy recipients in the crisis year was the cause. The expansion of the subsidy program during the crisis could have decreased the average "quality" of the subsidy recipients as compared to the precrisis years. This, in turn, could have lowered the average success of the subsidy program. In order to provide a formal test, we compare first-time subsidy recipients before and during the crisis. The results show that there are no systematic differences between these groups of firms in terms of innovation success indicators. In order to investigate whether SMEs' investment behavior has changed during the crisis, we focus on the subsample of companies that received subsidies before, during and after the crisis and find that these companies significantly reduced their R\&D expenses in 2009 . Hence, we conclude that the crowding out effect is not caused by the R\&D subsidy program expansion in the crisis years but that it is due to firm behavior. In order to cope with negative effects of the crisis, SMEs seem to have shifted funds during the crisis that they would have spent on R\&D projects in non-crisis years, to other business areas, such as keeping their stock of employees.

The countercyclical innovation policy of the BMBF is likely to have had a stabilizing effect for SMEs helping them to pay the wages of R\&D workers and to start new projects. The crowding out effect lasted only for one year after which SMEs recovered from the

\footnotetext{
14 Additionally, we compare firms that received subsidies before the crisis with firms that received subsidies after the crisis started in terms of other economic performance characteristics, like labor productivity and innovation sales, as was suggested by a reviewer, but do not find a significant difference there either. The results are presented in Table A4 in the Appendix A.
}

first shock of the crisis and returned to their pre-crisis R\&D investment behavior. The likelihood of negative long run effects for the economy is hence low.

A limitation of our study is that we can only focus on additionality effects of R\&D subsidies on R\&D input rather than on additionality effects in terms of R\&D output, a second measure of high interest for policy makers. ${ }^{15}$ While it is feasible to focus on input additionalities of R\&D funding since they occur in the immediate funding years, output effects are distributed over a period of years after the funding was received depending on the complexity of the project. This means that the output effects of pre-crisis funding are visible in the pre-crisis period as well as in the crisis and in post-crisis years. Since we cannot link particular innovation projects to their success, a comparison of output effects of projects funded before and during the crisis is not possible with the data at hand.

It is also worth mentioning that Germany is one of the biggest $\mathrm{R} \& \mathrm{D}$ spenders in the world. It is heavily specialized in manufacturing industries and has a high proportion of business R\&D. Germany's R\&D policy during the crisis may not work for other countries where business R\&D as a stock is lower and more volatile. It would be of great policy interest to compare different innovation policies during the crisis and their effectiveness for a set of countries with different characteristics.

Furthermore, it would be of high interest to test the effectiveness of research versus development subsidies during the past economic crisis. Unfortunately, our data set is not detailed enough to provide such an investigation, but other survey data such as the Flanders R\&D survey would allow for such an analysis (see Hottenrott et al., 2014). Another important factor that we cannot take into account due to data limitations is the effect of collaboration on the effectiveness of R\&D subsidies during the crisis (Czarnitzki et al., 2007). This is another important avenue for future research.

Lastly, the limitations of the matching approach should be acknowledged. Most important is the fact that the matching method only accounts for selection based on observable characteristics. In light of the previous literature that finds similar results for the direct R\&D subsidy program in Germany independent of the method that has been employed (see e.g., Almus and Czarnitzki, 2003; Czarnitzki et al., 2007; and Hussinger, 2008), we believe that this is a minor issue in our particular context.

\section{Acknowledgements}

We thank Benjamin Balsmeier, Martin Carree, Dirk Czarnitzki, Clemens Fuest, Georg Licht, Jeongsik Lee, Cindy Lopes Bento, Sadao Nagaoka, Hiroyuki Okamuro, Bettina Peters and Christian Rammer for helpful comments and Pia Neuer for proof reading. Furthermore, we would like to thank the participants of the CISS Summer School 2013, the PhD Workshop 2014 jointly organized by KU Leuven, University of Turin, Copenhagen Business School and ZEW, the DRUID Academy Conference 2014, the Hitotsubashi University's IO Labour Workshop 2014, the EARIE 2014, the APIC 2014 and the Paris School of Economics' IO Workshop. Furthermore, we want to thank three anonymous reviewers for their valuable comments.

\section{Appendix A.}

See Tables A1-A4.

\footnotetext{
${ }^{15}$ See Brautzsch et al. (2015) for a study examining R\&D output effects during the most recent crisis in Germany.
} 
Table A1

Descriptive statistics between the pre-crisis and (post-) crisis periods.

\begin{tabular}{|c|c|c|c|c|c|}
\hline & \multicolumn{2}{|c|}{ Pre-crisis period $(2006-2008) N=6172$} & \multicolumn{2}{|c|}{ Crisis-/post-crisis period (2009-2010) N=4335 } & \multirow[t]{2}{*}{$t$-Test } \\
\hline & Mean & Std. dev. & Mean & Std. dev. & \\
\hline \multicolumn{6}{|l|}{ Covariates } \\
\hline Sub_t-4 & 0.036 & 0.187 & 0.041 & 0.198 & \\
\hline Patemp & 0.004 & 0.030 & 0.004 & 0.033 & \\
\hline Lemp & 3.230 & 1.094 & 3.143 & 1.097 & $* * *$ \\
\hline Foreign & 0.054 & 0.226 & 0.043 & 0.202 & $* * *$ \\
\hline Export & 0.449 & 0.497 & 0.433 & 0.495 & $*$ \\
\hline Group & 0.226 & 0.418 & 0.203 & 0.402 & $* * *$ \\
\hline Lage & 3.033 & 0.866 & 3.088 & 0.839 & $* * *$ \\
\hline East & 0.345 & 0.476 & 0.341 & 0.474 & \\
\hline Salesgrowth & 5.287 & 9.349 & -1.172 & 16.691 & $* * *$ \\
\hline Credit & 225.297 & 65.640 & 225.888 & 62.202 & \\
\hline Credit_mvd & 0.034 & 0.182 & 0.034 & 0.181 & \\
\hline \multicolumn{6}{|c|}{ Outcome variables } \\
\hline $\mathrm{RD}$ & 0.110 & 1.055 & 0.086 & 0.534 & \\
\hline PRIVRD & 0.098 & 0.942 & 0.074 & 0.508 & $*$ \\
\hline RDINT & 0.019 & 0.089 & 0.019 & 0.085 & \\
\hline PRIVRDINT & 0.014 & 0.076 & 0.013 & 0.065 & \\
\hline RDEMP & 0.002 & 0.009 & 0.002 & 0.007 & \\
\hline PRIVRDEMP & 0.001 & 0.008 & 0.001 & 0.006 & \\
\hline
\end{tabular}

Note: ${ }^{*} p<0.1 ;{ }^{* *} p<0.05 ;{ }^{* * *} p<0.01$.

Table A2

OLS regression of the model variables on the outcome variables.

\begin{tabular}{|c|c|c|c|c|c|c|}
\hline & $\mathrm{RD}$ & RDINT & RDEMP & PRIVRD & PRIVRDINT & PRIVRDEMP \\
\hline \multirow[t]{2}{*}{ Sub } & $0.812^{* *}$ & $0.138^{* * *}$ & $0.011^{* * *}$ & $0.652^{* *}$ & $0.092^{* * *}$ & $0.007^{* * *}$ \\
\hline & $(0.339)$ & $(0.017)$ & $(0.002)$ & $(0.286)$ & $(0.015)$ & $(0.002)$ \\
\hline \multirow[t]{2}{*}{ Sub (2007) } & $-0.426^{* *}$ & $-0.029 *$ & $-0.003^{* *}$ & $-0.412^{*}$ & $-0.039^{* *}$ & $-0.004^{* *}$ \\
\hline & $(0.214)$ & $(0.017)$ & $(0.002)$ & $(0.212)$ & $(0.015)$ & $(0.002)$ \\
\hline \multirow[t]{2}{*}{ Sub (2008) } & -0.106 & -0.028 & 0.000 & -0.066 & -0.027 & 0.000 \\
\hline & $(0.142)$ & $(0.020)$ & $(0.002)$ & $(0.144)$ & $(0.018)$ & $(0.002)$ \\
\hline \multirow[t]{2}{*}{ Sub (2009) } & $-0.615^{*}$ & $0.059^{* * *}$ & $-0.004^{*}$ & $-0.525^{*}$ & $-0.052^{* * *}$ & $-0.003^{*}$ \\
\hline & $(0.344)$ & $(0.021)$ & $(0.002)$ & $(0.292)$ & $(0.018)$ & $(0.002)$ \\
\hline \multirow{2}{*}{ Sub (2010) } & $-0.567^{*}$ & $-0.046^{* *}$ & $-0.004^{*}$ & $-0.491^{*}$ & $-0.046^{* * *}$ & $-0.004^{* *}$ \\
\hline & $(0.341)$ & $(0.020)$ & $(0.002)$ & $(0.289)$ & $(0.017)$ & $(0.002)$ \\
\hline \multirow[t]{2}{*}{ Sub_t $t-4$} & 0.042 & 0.030 & 0.002 & 0.065 & $0.028^{*}$ & 0.002 \\
\hline & $(0.300)$ & $(0.019)$ & $(0.002)$ & $(0.251)$ & $(0.017)$ & $(0.002)$ \\
\hline \multirow[t]{2}{*}{ Patemp } & $3.061^{* *}$ & $0.651^{* * *}$ & $0.066^{* *}$ & $2.832^{* *}$ & $0.569^{* *}$ & $0.059^{* *}$ \\
\hline & (1.279) & $(0.245)$ & $(0.028)$ & $(1.201)$ & $(0.241)$ & $(0.026)$ \\
\hline \multirow[t]{2}{*}{ Lemp } & $0.104^{* * *}$ & -0.001 & 0.000 & $0.095^{* * *}$ & 0.001 & 0.000 \\
\hline & $(0.031)$ & $(0.001)$ & $(0.000)$ & $(0.026)$ & $(0.001)$ & $(0.000)$ \\
\hline \multirow[t]{2}{*}{ Foreign } & 0.243 & -0.004 & 0.001 & 0.216 & -0.003 & 0.001 \\
\hline & $(0.186)$ & $(0.006)$ & $(0.001)$ & $(0.156)$ & $(0.005)$ & $(0.001)$ \\
\hline \multirow[t]{2}{*}{ Export } & -0.011 & $0.010^{* * *}$ & $0.001^{* *}$ & -0.008 & $0.010^{* * *}$ & $0.001^{* * *}$ \\
\hline & $(0.023)$ & $(0.003)$ & $(0.000)$ & $(0.021)$ & $(0.003)$ & $(0.000)$ \\
\hline \multirow[t]{2}{*}{ Group } & -0.037 & -0.004 & -0.000 & -0.024 & -0.002 & -0.000 \\
\hline & $(0.041)$ & $(0.003)$ & $(0.000)$ & $(0.037)$ & $(0.003)$ & $(0.000)$ \\
\hline \multirow[t]{2}{*}{ Lage } & -0.035 & $-0.003^{* *}$ & $-0.000^{* *}$ & -0.030 & -0.001 & $-0.000^{* *}$ \\
\hline & $(0.027)$ & $(0.001)$ & $(0.000)$ & $(0.023)$ & $(0.001)$ & $(0.000)$ \\
\hline \multirow[t]{2}{*}{ East } & -0.000 & 0.004 & 0.000 & -0.003 & $0.005^{*}$ & 0.000 \\
\hline & $(0.036)$ & $(0.003)$ & $(0.000)$ & $(0.031)$ & $(0.003)$ & $(0.000)$ \\
\hline \multirow[t]{2}{*}{ Salesgrowth } & -0.001 & 0.000 & -0.000 & -0.000 & 0.000 & -0.000 \\
\hline & $(0.000)$ & $(0.000)$ & $(0.000)$ & $(0.000)$ & $(0.000)$ & $(0.000)$ \\
\hline \multirow[t]{2}{*}{ Credit } & -0.000 & $0.000^{*}$ & -0.000 & -0.000 & $0.000^{*}$ & -0.000 \\
\hline & $(0.000)$ & $(0.000)$ & $(0.000)$ & $(0.000)$ & $(0.000)$ & $(0.000)$ \\
\hline \multirow[t]{2}{*}{ Credit_mvd } & -0.104 & $0.016^{* *}$ & 0.001 & -0.086 & 0.013 & 0.000 \\
\hline & $(0.139)$ & $(0.008)$ & $(0.001)$ & $(0.120)$ & $(0.008)$ & $(0.001)$ \\
\hline \multirow[t]{2}{*}{ Constant } & -0.106 & -0.004 & 0.001 & -0.112 & $-0.014^{*}$ & -0.000 \\
\hline & $(0.091)$ & $(0.008)$ & $(0.001)$ & $(0.080)$ & $(0.008)$ & $(0.001)$ \\
\hline Observations & 10,527 & 10,527 & 10,527 & 10,527 & 10,527 & 10,527 \\
\hline Time dummies - F(3) & 1.510 & $3.01^{* *}$ & 1.910 & 1.610 & $2.64^{*}$ & 2.010 \\
\hline Industry dummies - F(8) & $4.63^{* * *}$ & $8.73^{* * *}$ & $9.89^{* * *}$ & $4.77^{* * *}$ & $8.01^{* * *}$ & $9.68^{* * *}$ \\
\hline Period interactions $-\mathrm{F}(20)$ & 0.930 & 1.160 & 1.340 & 0.900 & 1.260 & 1.360 \\
\hline
\end{tabular}

Note: ${ }^{*} p<0.1 ;{ }^{* *} p<0.05 ;{ }^{* * *} p<0.01$; robust standard errors in parentheses. 
Table A3

Additionally estimated coefficients of the probit model presented in Table 3 .

\begin{tabular}{lcc}
\hline & Coefficients & Std. err. \\
\hline Controlling for period differences & & \\
Sub_t-4_period & -0.199 & $(0.177)$ \\
Patemp_period & $12.221^{* * *}$ & $(2.045)$ \\
Lemp_period & -0.025 & $(0.049)$ \\
Foreign_period & -0.250 & $(0.202)$ \\
Export_period & -0.009 & $(0.111)$ \\
Group_period & 0.139 & $(0.124)$ \\
Lage_period & $-0.141^{* *}$ & $(0.062)$ \\
East_period & $-0.353^{* * *}$ & $(0.096)$ \\
Salesgrowth_period & 0.005 & $(0.004)$ \\
Credit_period & 0.001 & $(0.001)$ \\
Credit_mvd_period & 0.046 & $(0.382)$ \\
Mining_period & -0.563 & $(0.610)$ \\
Low-tech manufacturing_period & $0.256^{*}$ & $(0.150)$ \\
High-tech manufacturing_period & $0.372^{* *}$ & $(0.152)$ \\
Energy, water, recycling_period & 0.129 & $(0.247)$ \\
Wholesale_period & 0.523 & $(0.463)$ \\
Transportation_period & $0.554^{* *}$ & $(0.275)$ \\
ICT_period & 0.092 & $(0.178)$ \\
Consulting, advertising_period & $0.528^{* *}$ & $(0.233)$ \\
\hline
\end{tabular}

Note: ${ }^{*} p<0.1 ;{ }^{* *} p<0.05 ;{ }^{* * *} \mathrm{p}<0.01$.

Table A4

Further comparison of treated companies before and after the crisis.

\begin{tabular}{|c|c|c|c|c|}
\hline Additional indicators & $\begin{array}{l}\text { Treated } \\
\text { before } \\
2009 \text { - } \\
\text { mean value }\end{array}$ & $\begin{array}{l}\text { Treated } \\
\text { after } 2008 \\
\text { - mean } \\
\text { value }\end{array}$ & $t$-Test & p-Values \\
\hline Log labour productivity & -2.349 & -2.318 & & 0.502 \\
\hline Tangible assets (in Mio. EUR) & 3.017 & 3.034 & & 0.980 \\
\hline Capital intensity & 0.041 & 0.044 & & 0.608 \\
\hline Innovators & 0.829 & 0.855 & & 0.256 \\
\hline Log(new product sales + 1 EUR $)$ & 0.032 & 0.520 & & 0.324 \\
\hline
\end{tabular}

\section{References}

Aerts, K., Schmidt, T., 2008. Two for the price of one? Additionality effects of R\&D subsidies: a comparison between Flanders and Germany. Res. Policy 37, 806-822.

Aghion, P., Howitt, P., 2009. The Economics of Growth. MIT Press, Cambridge, Mass. Aghion, P., Saint-Paul, G., 1998. Virtues of bad times: interaction between productivity growth and economic fluctuations. Macroecon. Dyn. 2, 322-344.

Almus, M., Czarnitzki, D., 2003. The effects of public R\&D subsidies on firms' innovation activities: the case of Eastern Germany. J. Bus. Econ. Stat. 21 (2), 226-236.

Archibugi, D., Filipetti, A., Frenz, M., 2013a. Economic crisis and innovation: is destruction prevailing over accumulation. Res. Policy 42, 303-314.

Archibugi, D., Filipetti, A., Frenz, M., 2013b. The impact of the economics crisis on innovation: evidence from Europe. Technol. Forecasting Social Change 80, 1247-1260.

Arnold, J.M., Hussinger, K., 2005. Export behavior and firm productivity in German manufacturing: a firm-level analysis. Rev. World Econ. (Weltwirtschaftliches Archiv.) 141 (2), 219-243.

Arrow, K.J., 1962. Economic welfare and the allocation of resources for invention. In: Nelson, R.R. (Ed.), The Rate and Direction of Inventive Activity: Economic and Social Factors. National Bureau of Economic Research, Conference Series, Princeton University Press, Princeton, pp. 609-625.

Aschhoff, B., 2010. Who gets the money? The dynamics of R\&D project subsidies in Germany. Jahrb. Natl. Stat. 230 (5), 522-546.

Aschhoff, B., Baier, E., Crass, D., Hud, M., Hünermund, P., Köhler, C., Peters, B., Rammer, C., Schricke, E., Schubert, T., Schwiebacher, F., 2013. Innovation in Germany - Results of the Germany CIS 2006 to 2010. ZEW Documentation No. 13-01, Mannheim.

Bloom, N., 2008. Uncertainty and the dynamics of R\&D. Am. Econ. Rev. 97 (2), 250-255.

Bloom, N., Bond, S., Van Reenen, J., 2007. Uncertainty and investment dynamics. Rev. Econ. Stud. 74, 391-415.

Blundell, R., Costas Dias, M., 2000. Evaluation methods for non-experimental data. Fiscal Stud. 21 (4), 427-468.

Busom, I., 2000. An empirical evaluation of the effects of R\&D subsidies. Econ. Innovation New Technol. 9 (2), 111-148.

BMBF, BMWi, 2001. Innovationsförderung - Hilfen für Forschung und Entwicklung. Bonn/Berlin.
Brautzsch, H.-U., Guenther, J., Loose, B., Ludwig, U., Nulsch, N., 2015. Can R\&D subsidies counteract the economic crisis? Macroeconomic effects in Germany. Res. Policy 44, 623-633.

Cerulli, G., Poti, B., 2010. The Differential Impact of Privately and Publicly Funded R\&D on R\&D Investment and Innovation: The Italian Case. Sapienza Universita di Roma Doctoral School of Economics Working Paper 10-2010, Rome.

Czarnitzki, D., Ebersberger, B., Fier, A., 2007. The relationship between R\&D collaboration, subsidies and R\&D performance: empirical evidence from Finland and Germany. J. Appl. Econ. 22 (7), 1347-1366.

Czarnitzki, D., Fier, A., 2002. Do innovation subsidies crowd out private investment? Evidence from the German Service Sector. Konjunkturpolitik Appl. Econ. Q. 48 (1), 1-25.

Czarnitzki, D., Hussinger K., 2004. The Link Between R\&D Subsidies, R\&D Spending and Technological Performance. ZEW Discussion Paper No. 04-56, Mannheim.

Czarnitzki, D., Lopes Bento, C., 2013. Value for money? New microeconometric evidence on public R\&D grants in Flanders. Res. Policy 42 (1), 76-89.

David, P.A., Hall, B.H., Toole, A.A., 2000. Is public R\&D a complement or substitute for private R\&D? A review of the econometric evidence. Res. Policy 29 (4-5), 497-529.

Doraszelski, U., Jaumandreu, J., 2013. R\&D and productivity: estimating endogenous productivity. Rev. Econ. Stud. 80, 1338-1383.

European Commission, 1996. Community Frame for Public R\&D Subsidies, Brussels

Filipetti, A., Archibugi, D., 2011. Innovation in times of crisis: national systems of innovation, structure and demand. Res. Policy 40 (2), 179-192.

Freeman, C., Clark, J., Soete, L., 1982. Unemployment and Technical Innovation: A Study of Long Waves and Economic Development. Pinter, London.

Gelabert, L., Fosfuri, A., Tribo, J.A., 2009. Does the effect of public support for R\&D depend on the degree of appropriability. J. Ind. Econ. 57 (4), 736-767.

Goerg, H., Strobl, E., 2007. The effect of R\&D subsidies on private R\&D. Economica $74,215-234$.

Gonzalez, X., Jaumandreu, J., Pazo, C., 2005. Barriers to innovation and subsidy effectiveness. RAND J. Econ. 36 (4), 930-950.

Gonzalez, X., Pazo, C., 2008. Do public subsidies stimulate private R\&D spending. Res. Policy 37 (3), 371-389.

Griliches, Z., 1979. Issues in assessing the contributions of research and development to productivity growth. Bell J. Econ. 10 (1), 92-116.

Griliches, Z., Mairesse, J., 1984. Productivity and R\&D at the firm level. In: Griliches, Z. (Ed.), R\&D, Patents and Productivity. University of Chicago Press, Chicago, IL, pp. 339-374

Grossman, G.M., Helpman, E., 1994. Endogenous innovation in the theory of growth. J. Econ. Perspect. 8 (1), 23-44.

Hall, B.H., 1990. The impact of corporate restructuring on industrial research and development. Brooking Pap. Econ. Act. 1, 85-136.

Hall, B.H., 1992. Investment and Research and Development at the Firm Level: Does the Source of Financing Matter? NBER Working Paper 4096, Cambridge.

Harhoff, D., 1998. Are there financing constraints for R\&D and investment in German manufacturing firms. Ann. d’Écon. Stat. 49/50, 421-456.

Himmelberg, C., Petersen, B., 1994. R\&D and internal finance: a panel study of small firms in High-Tech industries. Rev. Econ. Stat. 76 (1), 38-51.

Hottenrott, H., Lopes Bento, C., Veugelers, R., 2014. Direct and Cross-Scheme Effects in a Research and Development Subsidy Program. ZEW Discussion Paper 14-107. ZEW, Mannheim.

Hussinger, K., 2008. R\&D and subsidies at the firm level: an application of parametric and semi-parametric two-step selection models. J. Appl. Econ. 23 $729-747$.

Klette, T.J., Møen, J., Griliches, Z., 2000. Do subsidies to commercial R\&D reduce market failures? Res. Policy 29, 471-495.

Kulicke, M., Hufnagl, M., Brandt, T., Becker, C., Berteit, H., Grebe, T., Kirbach, M., Lübbers, T., 2010. Evaluierung des Programmstarts und der Durchführung des Zentralen Innovationsprogramms Mittelstand (ZIM). Study on behalf of the Federal Ministry of Economics and Technology. Fraunhofer ISI, Karlsruhe, Berlin.

Makkonen, T., 2013. Government science and technology budgets in times of crisis. Res. Policy 42, 817-822.

OECD, 2009. The Impact of the Global Crisis on SME and Entrepreneurship Financing and Policy Responses.

OECD, 2012. Innovation in the Crisis and Beyond, in: OECD Science, Technology and Industry Outlook 2012.

OECD, 2012. OECD Employment Outlook 2012.

OECD, 2013. Main Science and Technology Indicators.

OECD, Eurostat, 2005. Oslo-Manual. Proposed Guidelines for Collecting and Interpreting Innovation Data, 3rd ed. OECD, Paris.

Paunov, C., 2012. The global crisis and firms' investment in innovation. Res. Policy 41, 24-35.

Peters, B., Rammer, C., 2013. Innovation panel surveys in Germany. In: Gault, F. (Ed.), Handbook of Innovation Indicators and Measurement. Edward Elgar, Cheltenham and Northhampton, pp. 135-177.

Rafferty, M., Funk, M., 2008. Asymmetric effects of the business cycle on firm-financed R\&D. Econ. Innovation New Technol. 17 (5), 497-510.

Rammer, C., 2011. Auswirkungen der Wirtschaftskrise auf die Innovationstätigkeit der Unternehmen in Deutschland. ZEW Discussion Paper 11-070, Mannheim.

Rammer, C., Ebling, G., Gottschlak, S., Janz, N., Peters, B., Schmidt, T., 2003. Innovationsverhalten der deutschen Wirtschaft. ZEW Report. ZEW, Mannheim. Available at: http://ftp.zew.de/pub/zew-docs/mip/02/ib_2002pdf 
Rosenbaum, P.R., Rubin, D.B., 1983. The central role of the propensity score in observational studies for causal Effects. Biometrika 70 (1), 41-55.

Rubin, D.B., 1977. Assignment to treatment group on the basis of a covariate. J. Educ. Stat. 2 (1), 1-26.

Schmookler, J., 1966. Invention and Economic Growth. Harvard University Press, Cambridge, MA.

Schumpeter, J., 1939. Business Cycles: A Theoretical, Historical, and Statistical Analysis of the Capitalist Process, 2nd vol. McGraw-Hill, New York.

Shleifer, A., 1986. Implementation Cycles. J. Polit. Econ. 94 (6), 1163-1190.

Stifterverband, 2013. FuE-Datenreport 2013. Tabellen und Daten, Essen.
Stiglitz, J., 1993. Endogenous Growth and Cycles. NBER Working Papers 4286 Cambridge.

Takalo, T., Tanayama, T., Toivanen, O., 2008. Evaluating Innovation Policy: A Structural Treatment Effect Model of R\&D Subsidies. Bank of Finland Research Discussion Papers 7, Helsinki.

Wallsten, S.J., 2000. The effects of government-industry R\&D programs on private R\&D: the case of the small Business Innovation Research Program. RAND J. Econ. 31 (1), 82-100.

Zúñiga-Vicente, J., Alonso-Borrego, C., Forcadell, F., Galan, J., 2014. Assessing the effect of public subsidies on firm R\&D investment: a survey. J. Econ. Surv. 28 (1), 36-67. 